\title{
The Thames: Arresting Ecosystem Decline and Building Back Better
}

\author{
Martin Richardson *(D) and Mikhail Soloviev*(D) \\ Department of Biological Sciences, Royal Holloway University of London, Egham, Surrey TW20 0EX, UK \\ * Correspondence: Martin.Richardson.2014@live.rhul.ac.uk (M.R.); Mikhail.Soloviev@rhul.ac.uk (M.S.)
}

Citation: Richardson, M.; Soloviev, M. The Thames: Arresting Ecosystem Decline and Building Back Better. Sustainability 2021, 13, 6045. https:// doi.org/10.3390/su13116045

Academic Editors: Andrzej Wałega and Alban Kuriqi

Received: 16 April 2021

Accepted: 24 May 2021

Published: 27 May 2021

Publisher's Note: MDPI stays neutral with regard to jurisdictional claims in published maps and institutional affiliations.

Copyright: (c) 2021 by the authors. Licensee MDPI, Basel, Switzerland. This article is an open access article distributed under the terms and conditions of the Creative Commons Attribution (CC BY) license (https:/ / creativecommons.org/licenses/by/ $4.0 /)$.

\begin{abstract}
The Thames is an iconic river of cultural and historical importance. A cyclical process of deterioration during the last two centuries, followed by technology-driven restorations, including two major sanitation projects with a third currently underway, has produced detrimental effects on the Thames ecosystem. This paper overviews the river ecology, pollution and other anthropogenic pressures, which lead to biodiversity loss and the proliferation of non-native, pollution-tolerant species. This article further reviews past and current management, sampling and assessments trends and provides an objective overview of remediation, restoration and monitoring needs, practices and research gaps. Here, we argue that restoration work, if maladapted, can be ineffective in improving resilience or have unexpected side effects that make matters worse rather than better. We explain the need for a broader view of river restoration and management including consideration of species transplants in achieving overall sustainability against a backdrop of accelerating change in the Anthropocene.
\end{abstract}

Keywords: the Thames; ecosystem; pollution; biodiversity; non-native species; ecosystem management; remediation; restoration; monitoring

\section{Introduction}

The Thames catchment covers an area of over $16,000 \mathrm{~km}^{2}$. The Thames system is composed of several connected subsystems which can be divided into 'natural' or geographically described, and manmade, engineered elements, each of which has cobenefits and trade-offs beyond their initial purpose (Figure 1). The river has a low gradient and is well-mixed and generally shallow. Above Richmond, the river has been transformed into a series of lacustrine stretches connected by locks and weirs (Figure 2, Supplementary Figure S1). The dominant factor governing species distributions in the tidal Thames is the increasing salinity from Teddington down towards the estuary although flow regime, brine from desalination plants, groundwater inputs, warm water from sewers and power stations, chemical pollution and low oxygen saturation, each of which can create temporary and localised effects, also play a part. The Teddington weir delineates the tidal river; saline conditions intrude as far as Teddington during times of low flow. Water is released from the Richmond lock during high flow events in the upper catchment, which can alter salinity and flow downriver. The Thames barrier at Woolwich, in association with other elements of the Thames flood protection system (Figure 3, Supplementary Figure S1) [1], provides flood control, particularly for the low-lying areas of London. The barrier is only closed for short durations when flow control is needed, allowing for fish passage most of the time. The barrier was completed in 1984 and designed to withstand a projected annual sea-level rise of $6 \mathrm{~mm}$ to $8 \mathrm{~mm}$, which appeared more than adequate at the time. However, analysis of the compounding effects of accelerating sea-level rise, extreme rainfall events and storm surges is raising the possibility of it being overwhelmed sooner [2]. 


\section{Geographic}

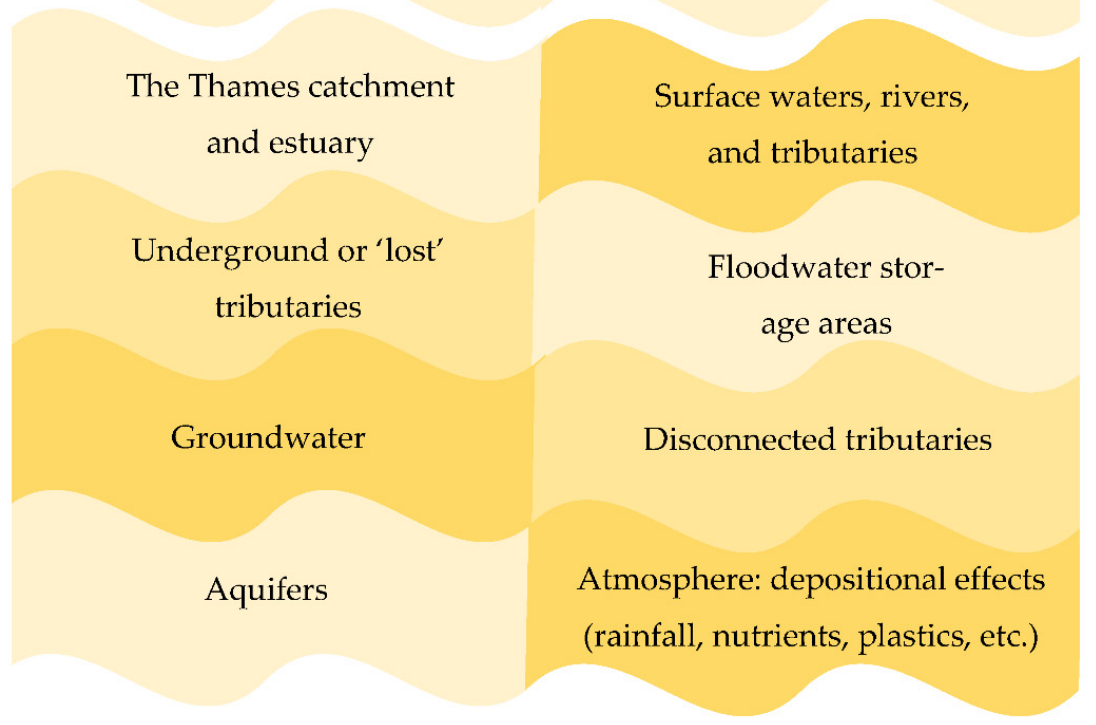

\section{Engineered}

Man-made canals, architectural

streams, reservoirs and lakes

Flood protection and other flow control systems

Drinking water distribution networks

Sewage system networks

Figure 1. Natural and engineered components of the Thames catchment system.

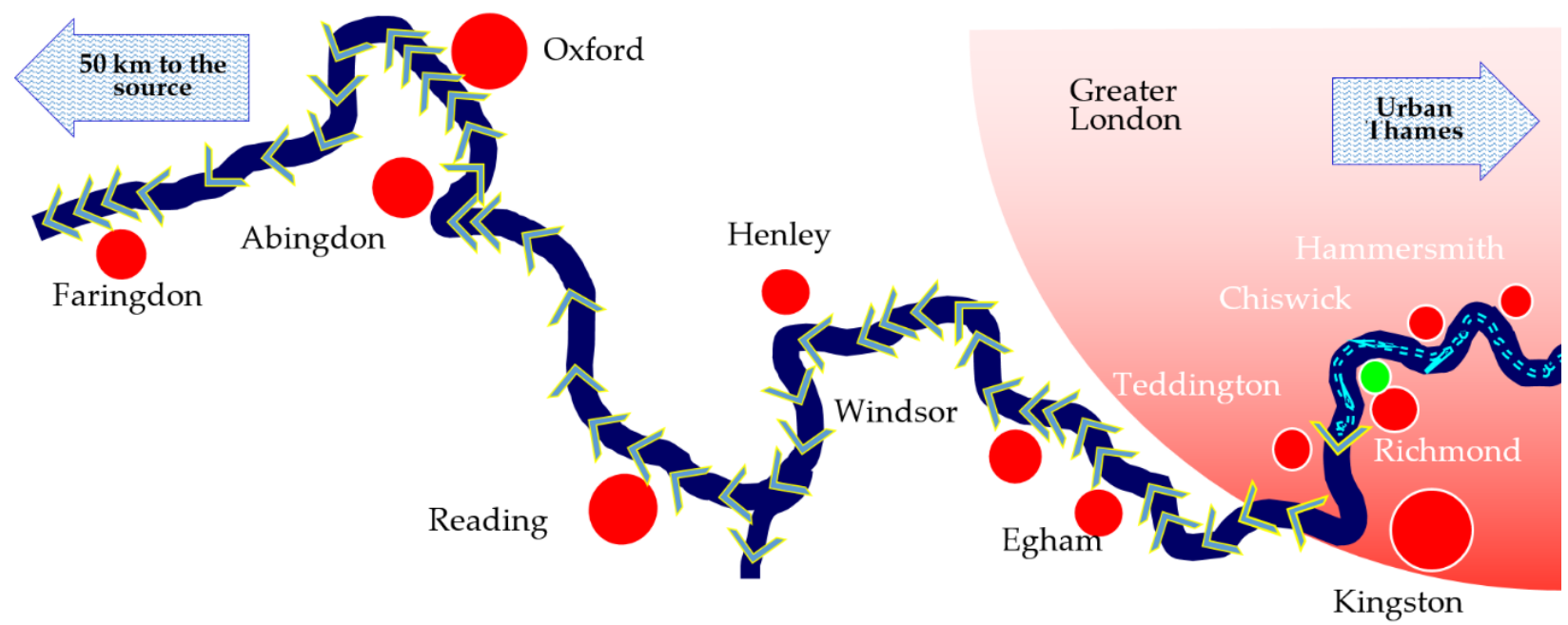

Figure 2. Natural and engineered components of the Thames catchment system. Non-tidal reaches of the Thames with 45 locks (arrowheads). The Teddington lock and the weir mark the tidal river limits. The double-dashed line shows tidal areas (brackish water). The Royal Botanic Gardens (Kew) are indicated in green. 


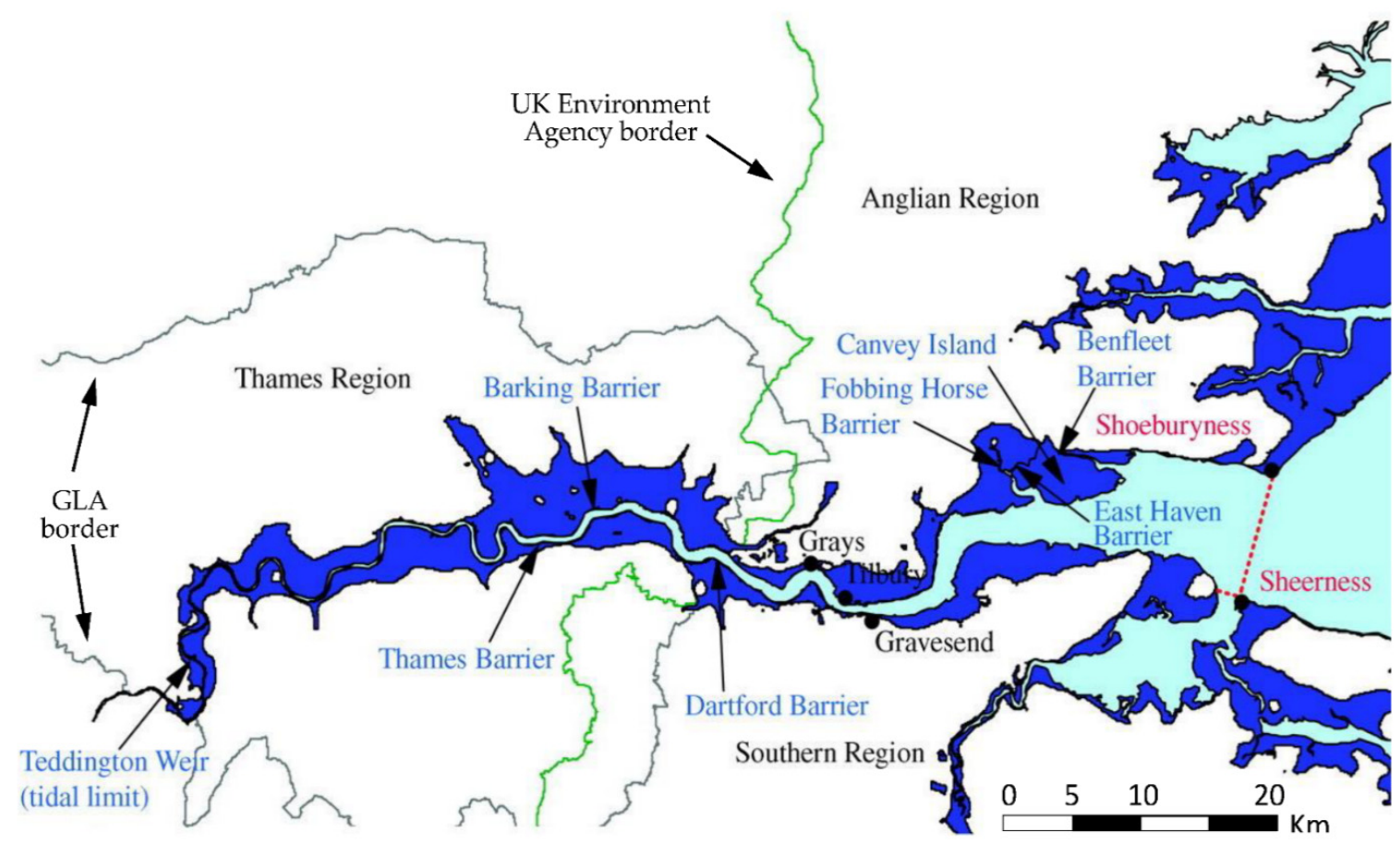

Figure 3. The tidal Thames flood-plain with defences labelled in light blue. The Greater London Area (GLA) is indicated with a grey border. The red dotted line shows the lower limit of the flood protection system. The green boundary delineates the operational area of the UK Environment Agency at the time (2005). Modified from [1], reproduced with permission.

\section{Ecosystem Services}

\subsection{Recreation, Transport and Water}

Historically, water depth and navigability were maintained for industrial barge transport. More recently, the Canal and Rivers Trust (CRT) estimated that on average some 246,000 boating enthusiasts visit the canal and river network each week [3]. Wash from boats, even small craft, can greatly affect aquatic life, mobilise sediment and damage riverbanks. However, boating groups, anglers' associations and other groups participate in maintaining the river and positively influence development and restoration work. The upper reaches are monitored for changes to bathymetry and depth for possible dredging needs, and dredging is also conducted in the lower reaches and in the estuary. Large silt banks have built up in downstream stretches. They change morphology, reduce flow capacity, and accumulate xenobiotics such as metals that adhere (adsorb) to the particles and increase the larval survival in invasive species [4]. The sediment is largely anoxic with occasional black, sulphide deposits [5] inhibiting oxygenation by worms or colonization by plants. However, the lack of oxygen in combination with the increased organic matter aids in the reduction of nitrate and preserves natural revetments (e.g., wood or spiling) that would otherwise rapidly degrade. Deposits of nutrients, particularly phosphorus, accumulate in the mud and can be remobilized through disturbance caused by construction work, boat traffic or dredging in the river, but also promote carbon sequestration and contaminant uptake through increased vegetation [6,7]. Damage caused by construction work is sometimes traded-off against a contribution (funds) towards restoration, but nutrient release increases algal growth and aids phosphorous-loving (and excreting) aquatic species belonging to the Ponto-Caspian group such as Dreissena polymorpha (Pallas, 1771) [8,9].

Large abstractions are taken upstream of Teddington for agriculture and drinking water and major inputs of wastewater occur as sewage treatment effluent. Increasing domestic and industrial water use means that effluent from sewage treatment plants can comprise a major component of stream flow downstream of treatment facilities. At times, wastewater can even comprise the majority of the river flow. Water abstraction from above the tidal area and changes in rainfall with increased intensity of storms have exaggerated 
the extremes in flow regimes with periods of reduced flow, many more ephemeral streams and increased flooding. There are several remaining Thames tributaries, which provide refuge for fish during times of low oxygen in the main channel, but many have been closed off. Large stretches of the banks and islands have been armoured to protect against erosion and the river has generally narrowed. Sediment inputs from agricultural tilling [10] have created mud banks which decrease the volume of the river basin through related algal and silt deposits. Modifications including increased reservoir capacity such as the opening of the Wraysbury reservoir in 1970 provide additional stored capacity to maintain improved flows during periods of drought [11]. Licensing has been brought in to manage abstractions, which frequently increase during periods of drought, reducing flows to the point where they cause stress to the ecosystems [12].

\subsection{Fisheries and Ecosystem Decline}

Prior to 1800, the river was clean enough to support large populations of many species [13]. Diadromous species which use the ocean and freshwater at different stages of their lifecycle including smelt, salmon, eels, sprat and flounder, were caught for food along the river for centuries. Fishing and fisheries have been an integral part of the Thames community for several hundred years. Fishing communities lived for generations at several locations along the river including Kew and Chiswick [14]. The fishery included coarse fish species which are not typically consumed today such as pike, however, they are still currently important to anglers. In the past, large quantities of shellfish, starfish and shrimp were landed from the estuary [15]. Starfish were caught for use as fertiliser on crops. The river was wider in many places, with extensive gravel banks that once attracted large spawning aggregations of smelt. In recent times, fishing has been reduced to mainly recreational angling for coarse species including carp and pike in the river, and some sea angling in the estuary. Small but important commercial fisheries continue in the estuary for whelks, cockles and oysters. The modern Thames above Teddington is freshwater and contains a typical UK species assemblage for a degraded river (Figure 4) including non-native mussels, fish, invertebrates and invasive aquatic plants [16].

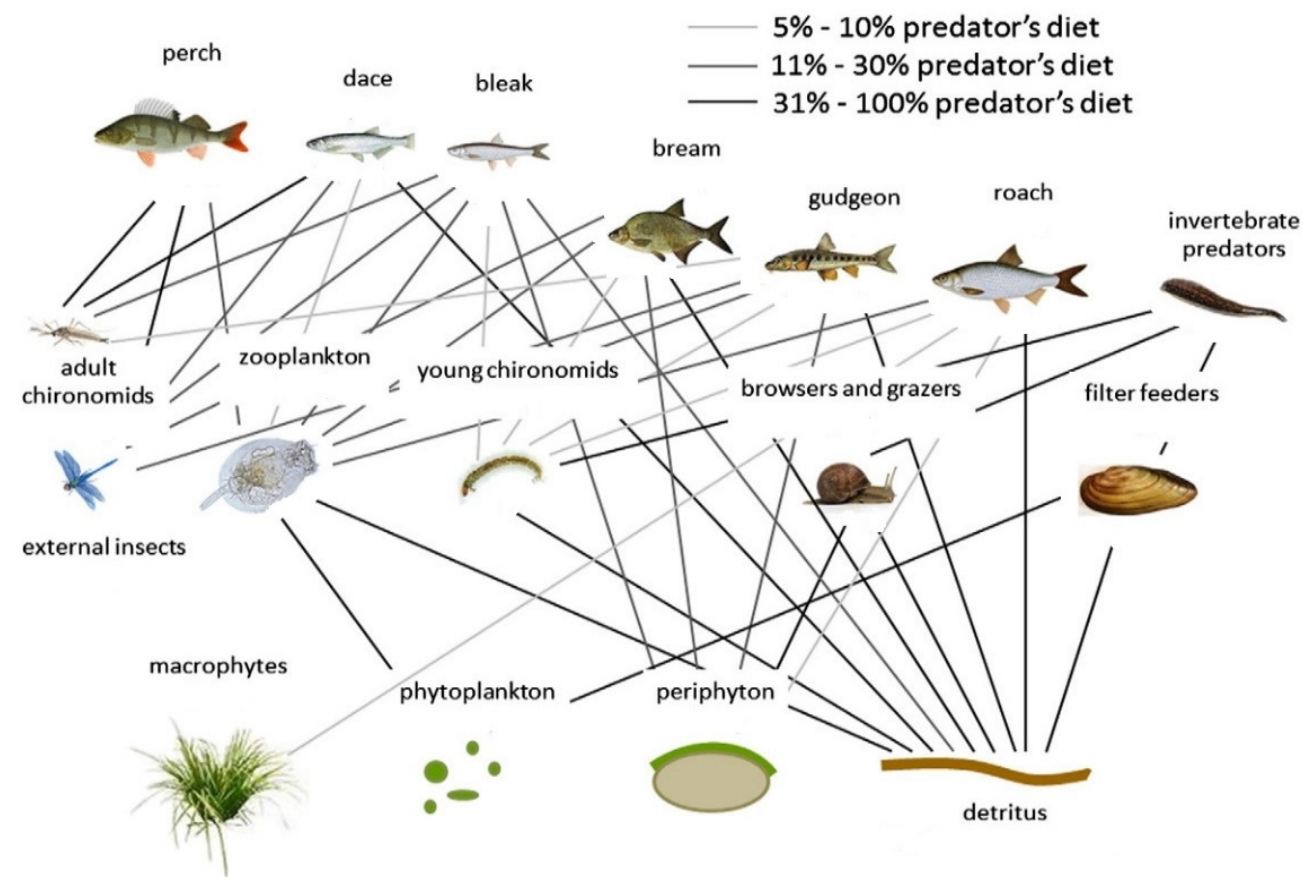

Figure 4. Simplified freshwater food web from the non-tidal part of the Thames. Note that no non-native species are shown. Modified from [16], reproduced with permission. 
Water is well oxygenated after passing over the weirs, which causes spikes in saturation in the reaches immediately below and maintaining localised communities of freshwater species, especially in the area above Richmond, including native unionid mussels and, more recently, non-native bivalves. However, these primarily freshwater faunae are sensitive to low flows caused by periods of drought and abstractions, which are taken further upstream. In the past, this has given rise to cyclical declines in many taxa, including caddisflies, mayflies, unionid mussels, isopods and leeches, as occurred, for example, during pronounced drought in 1989 and 1990. Some species of fish including eels and snakehead are able to leave the water to navigate weirs and obstacles. However, barriers still impede progress both upriver and downriver during migration. Potentially invasive bivalves including the zebra mussel, which were predicted to increase substantially, have now declined from this part of the river.

The Teddington weir marks the transition between the purely freshwater and tidal parts of the river. The lock gates are lowered at high slack water and fish passage throughout the river has recently been provided at locks and weirs. Downriver from Teddington, the water has low salinity most of the time, however, this varies with the seasons and flow. Many freshwater fish including barbel, Barbus barbus (Linnaeus, 1758), and carp, Cyprinus carpio (Linnaeus, 1758), are tolerant of brackish water and can thrive in even the lower reaches. A total of approximately 120 species of fish live in the Thames $[3,17,18]$ but many are rare, non-native (exotic) or not representative of resident populations (Table 1) [3,18,19]. Less than $\sim 20$ pollution tolerant species comprise a majority abundance (Table 2) [20].

Table 1. Non-native fish species recorded from the Thames (complete catchment) ${ }^{1}$.

\begin{tabular}{cccc}
\hline Common Name & Species & Source & Suspected Origin $^{2}$ \\
\hline Wel's catfish & Silurus glanis (Linnaeus, 1758) & {$[17]$} & Stocking \\
Siberian sturgeon & Acipenser baerii (Brandt, 1869) & {$[3]$} & Pet trade \\
Sterlet & Acipenser ruthenus (Linnaeus, 1758) & {$[3]$} & Pet trade \\
Short-snouted seahorse & Hippocampus hippocampus (Linnaeus, 1758) & {$[17]$} & Unknown \\
Bitterling & Rhodeus sericeus (Pallas, 1776) & Ornamental \\
Koi carp & Cyprinus carpio (Linnaeus, 1758) & {$[17]$} & Ornamental \\
Grass carp & Ctenopharyngodon idella (Valenciennes, 1844) & {$[3]$} & Stocking \\
Pumpkinseed & Lepomis gibbosus (Linnaeus, 1758) & Stocking \\
Sunbleak & Leucaspius delineatus (Heckel, 1843) & {$[3]$} & Pet trade \\
Topmouth gudgeon & Pseudorasbora parva (Temminck and Schlegel, 1846) & {$[3]$} & Pet trade \\
Zander & Sander lucioperca (Linnaeus, 1758) & {$[3]$} & Stocking \\
Goldfish & Carassius auratus (Linnaeus, 1758) & {$[17]$} & Aquaculture \\
Goldfish $\times$ carp hybrid & & {$[18]$} & \\
Orfe & Leuciscus idus (Linnaeus, 1758) & {$[17]$} & Ornamental \\
Bream $\times$ Orfe hybrid & & {$[18]$} & \\
Rainbow trout & Oncorhynchus mykiss (Walbaum, 1792) & Stocking \\
Brook trout & Salvelinus fontinalis (Mitchill, 1814) & Stocking \\
Fathead minnow & Pimephales promelas (Rafinesque, 1820) & {$[18]$} & Ornamental \\
Guppy & Poecilia reticulata (Peters, 1859) & {$[17]$} & Ornamental \\
European catfish & Silurus glanis (Linnaeus, 1758) & Stocking & \\
\hline
\end{tabular}

${ }^{1}$ Unusual, exotic species are mentioned from time to time in the media as curiosities when caught by anglers. Many non-native species originate from imports for food, bait for fishing, and the pet and ornamental fish trade. They are frequently released into surface waters when they become too big for an aquarium or pond. ${ }^{2}$ The explicit means of arrival is not usually known. Additional, cryptic species probably exist in the river, however, most are unlikely to sustain reproducing populations. 
Table 2. Principal fish species in the tidal Thames, from [20].

\begin{tabular}{cc}
\hline Common Name & Species \\
\hline European smelt & Osmerus eperlanus (Linnaeus, 1758) \\
European eel & Anguilla anguilla (Linnaeus, 1758) \\
Common dace & Leuciscus leuciscus (Linnaeus, 1758) \\
Common goby & Pomatoschistus microps (Krøyer, 1838) \\
Dover sole & Solea solea (Linnaeus, 1758) \\
European seabass & Dicentrarchus labrax (Linnaeus, 1758) \\
European sprat & Sprattus sprattus (Linnaeus, 1758) \\
Flounder & Platichthys flesus (Linnaeus, 1758) \\
Herring & Clupea harengus (Linnaeus, 1758) \\
Stickleback & Gasterosteus aculeatus (Linnaeus, 1758) \\
Pouting & Trisopterus luscus (Linnaeus, 1758) \\
Roach & Rutilus rutilus (Linnaeus, 1758) \\
Sand goby & Pomatoschistus minutus (Pallas, 1770) \\
Whiting & Merlangus merlangus (Linnaeus, 1758) \\
\hline
\end{tabular}

The tidal Thames supports a variety of migratory and non-native birds (swans, ducks, geese and other wildfowl) and a variety of fish (flounder, bass and mullet to name a few) as well as invertebrates and molluscs, including freshwater snails and bivalves. Aquatic mammals such as seals and dolphins mainly use the estuary but will on occasion come upriver as far as Teddington. In addition, there are a variety of other mammals including foxes, water voles, cats and rats. Recent increases in mammal populations in the Thames estuary do not necessarily translate to improved health of the river but may be due to other causes including behavioural changes as marine mammal colonies are known to relocate for reasons including seeking refuge from disturbance. Certainly, bioaccumulation of toxins in fish can be expected to have profound effects on animals higher up the food web, especially as it has been shown that increases in particulate matter in water can increase uptake of toxic chemicals [21]. Sea grass occurs off the Essex coast but is under increasing pressure, especially from sediment [22]. Native and non-native molluscs occur in the estuary, and the most abundant is the invasive slipper limpet, Crepidula fornicata (Linnaeus, 1758). Despite recent declines, there are surviving fisheries for the native oyster, Ostrea edulis (Linnaeus, 1758), the imported American oyster, Crassostrea gigas (Thunberg, 1793), as well as the endemic cockle, Cerastoderma edule (Linnaeus, 1758), and whelks.

\section{Pollution}

The combined sewer network disposes of domestic and industrial waste as well as urban drainage and can release raw sewage, with added hydrogen peroxide, to the river, particularly during periods of heavy rain or flooding due to limited capacity [21]. Historical levels of 150 million tonnes a year were discharged in the 1850s. Around 40 million tonnes were still being released to the river in 2011 but recent improvements have reduced this to 18 million tonnes, the majority entering the river higher in the tidal reaches at the Hammersmith, Lots Road and Western Pumping stations [17,23,24]. In the London area, many tributaries have been lost and built over, with some assimilated into the sewer system [25]. Nutrient inputs from farming and livestock stimulate algal growth and related bacterial and viral communities [26]. These amplify greenhouse gases released by the river and promote growth and pathogenicity in microbial communities. Microbial assemblages are affected by antibiotics released in effluent from sewage treatment works $[27,28]$. Antibiotics may also trigger toxin release in Harmful Algal Blooms (HABs) by initiating lysis, causing a cascading reaction throughout the bloom in response to the presence of cyanotoxin in the water [29-31]. Oxygen depletion occurs in the lower reaches of rivers due to bacterial respiration associated with the consumption of organic material and the subsequent senescence and decomposition. Tidal areas of the river Thames are affected by oxygen depletion, partially because of the periodic sewage release (Figure 5, Supplementary Figure S1) [32] and algal growth stimulated by an excess of 
nutrients, especially at the mouth of the estuary, which is a common and increasing feature of many rivers $[33,34]$. Other pollutants enter the water from historic (unlined) landfills (Figure 6, Supplementary Figure S1) [35,36], which become grossly exposed when subjected to increasing erosion [36].
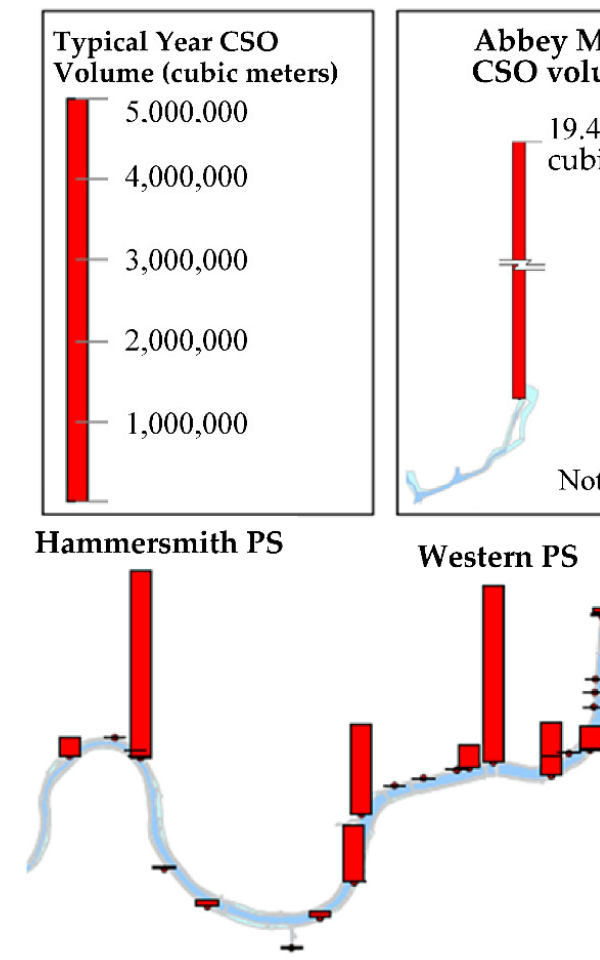

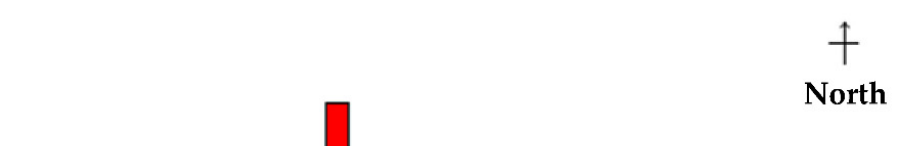

Figure 5. Typical annual sewage releases (prior to 2013) from combined sewer system outfalls and pumping stations (PS) in the upper tidal Thames. CSO stands for combined sewage overflow. Red bars indicate release volume in cubic metres; all bars are shown to the same scale, except for the Abby Mills CSO. Pumping stations raise sewage to higher elevation levels to facilitate gravitational flow in the system of pipes towards the estuary. Modified from [32], reproduced with permission.

Rainfall can more than double flows in the sewer network, which is connected to the river at multiple locations through outfalls. In some Thames tributaries, such as the river Lee, flows are greatly reduced due to water abstractions for agriculture and drinking water. Downstream of these locations, especially at times of low flow, the river can be over $40 \%$ effluent. Sewage treatment does not remove all pollutants from water. Some pharmaceuticals, which are specifically designed to be effective at a low dose, including psychotropic drugs, many hormones, antibiotics, pain killers and antidepressants remain in the effluent $[31,37,38]$. Many are known to have detrimental effects on aquatic animals $[39,40]$ and can degrade to potentially more harmful transformation products through biotic and abiotic processes [41,42]. After treatment, wastewater and its associated sludge is frequently reused for crop irrigation and fertilisation, which allows contaminants to circulate and further accumulate in the environment. In a recent study, sediment samples collected from multiple locations in the tidal Thames revealed contamination from persistent organic pollutants such as PCBs and heavy metals [43]. Soil samples taken from an island in the river showed increasing contaminant concentrations from a $20 \mathrm{~cm}$ to $40 \mathrm{~cm}$ depth, which is suggestive of accumulation in riverbanks and other areas subjected to flooding (Supplementary Figures S2 and S3, Supplementary Table S1). Similar findings have been reported elsewhere [44]. 


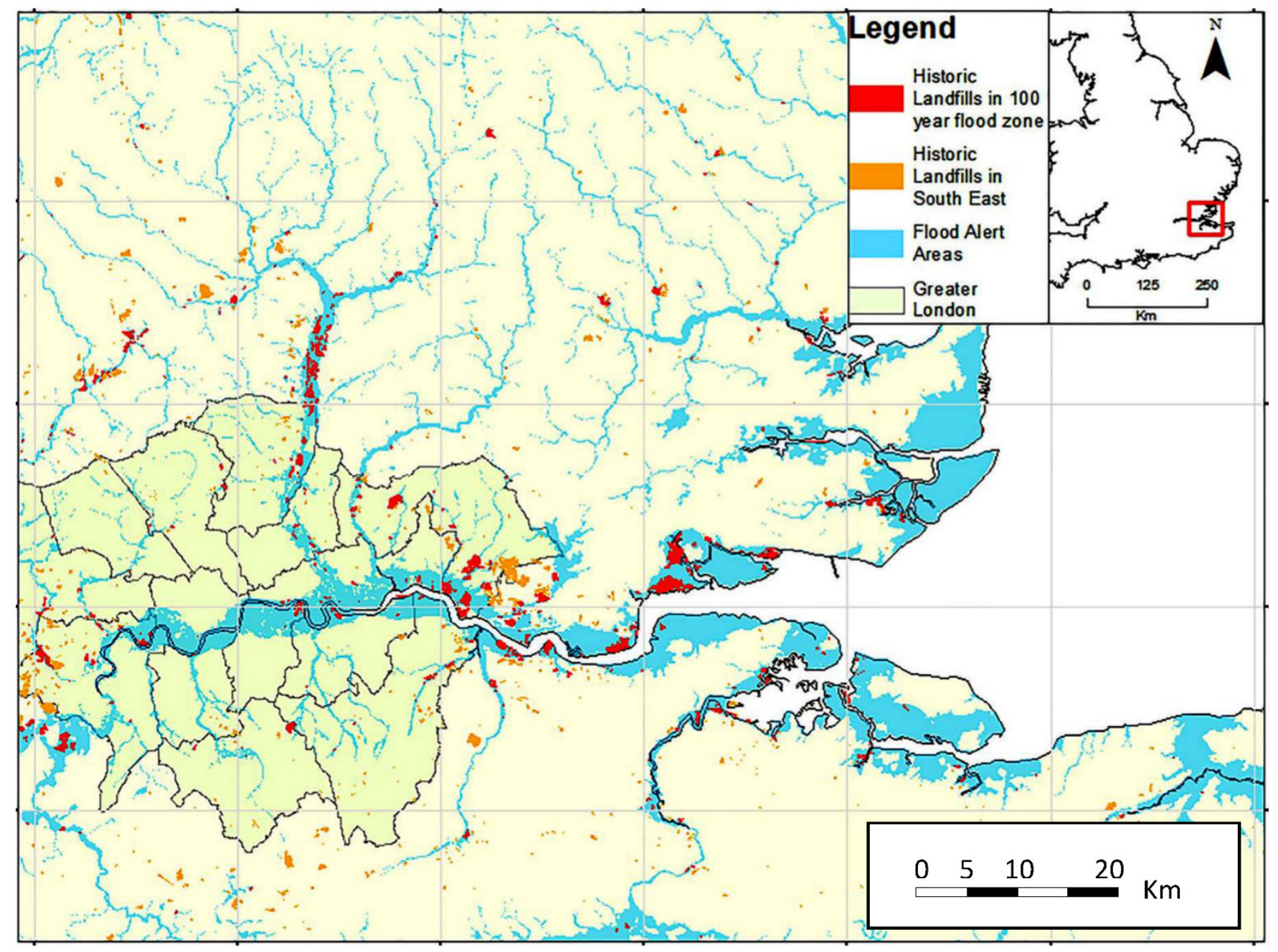

Figure 6. Historic landfills in the Thames Estuary. Blue areas are designated at risk of flooding by the Environment Agency, the red and yellow areas are historic landfills that are leaching contaminants. Landfills are also vulnerable to subsidence thereby amplifying the effects of sea-level rise and flooding. Reproduced from [36] under a Creative Commons Attribution Generic License.

The Thames, as well as other rivers, now contain large quantities of nano-plastics, micro-fibres and other micro-plastics which cannot feasibly be removed but aggregate with biogenic particles and eventually settle into the sediment [45] or are flushed into the ocean. However, these are continually replenished by others through aerial deposition as well as run-off from the land and roads [46,47]. Materials released into the river, including rubbish and sewage, especially in the upper regions of the tidal Thames, do not completely flush but move back and forth with the tides and may take several weeks or even months to leave the estuary during times of low flow [48]. Most of the organic material decomposes within a few days, but fats take much longer. 'Fatbergs', solid masses of combined fats and other waste including synthetic (plastic) 'wet-wipes', can form hard accretions in sewers several hundred metres long and harbour toxic chemicals and antibiotic-resistant pathogens, which can be released directly into the river through outfalls [28,49].

In the early 19th century, the Thames was used as an open sewer. The fast growth of the London population led to major increases in the amount of sewage discharged to the Thames and tributaries, severely reducing the oxygen content of the water. A campaign to improve public health led to the opening of the London sewer system in 1870, which improved the situation. However, the system became overwhelmed again in the first half of the 20th century and stretches of the tidal Thames turned anoxic with widespread hypoxia, resulting in a major depletion of aquatic life. Prior to upgrades of the sewer network in 
the 20th century, the river was declared 'biologically dead'. Between the early 1960's and late 1970 's, the river began to recover from severe pollution, and much was made of the return of many North Sea coastal fish species to the Thames, especially salmon [50,51]. This reflected contemporary ideas regarding the reversible nature of environmental degradation and the belief that the river could be returned to pristine conditions one species at a time with technical improvements of the system. The return of fish to the river was described as a 'recovery', but changes following previous improvements to the London sewage system were not measured and comprehensive before and after data were not collected [5].

\section{Biodiversity Loss}

Many native species of all taxa are in decline and local extinction may be inevitable for populations of native mussels, salmonids (smelt, trout and salmon), several plants, gastropods and some types of river flies. Continuing occurrence does not necessarily mean that there is potential to recover species. Population decline beyond a certain minimum level of genetic diversity might take decades to reverse. Deteriorating environmental conditions and extremes of weather further impede recovery and could make it unattainable. For example, fluctuation in eel populations is a typical indicator of population decline in species with high reproductive capacity [52]. This, as well as the precipitous declines in river flies [53] and the continuing decline in native mussels [54,55], is to be expected and provide typical examples of the urban river syndrome. Biodiversity loss can occur through the extinction of an individual species but also through the chronic decline in the abundance of subpopulations. Species are not generally highly localized except perhaps for the smelt spawning grounds at Kew, and unionid mussels at Richmond; other species such as cockles and flounder occur in large numbers. Whilst being isolated in different local habitats at different times of year and varying stages of their lifecycle, many species manage to survive the occasional serious pollution events and escape mass die-offs.

\section{Non-Native Species}

The Thames is home to an increasing number of non-native species [56] including a Ponto-Caspian assemblage and elements of American and Asian freshwater assemblages. Around 100 have been recorded from the Thames [57] and there will certainly be more cryptic species that have gone undetected. Potentially, many more non-native plants and animals occur on land and in gardens within the catchment area as the ecosystem adapts to environmental change. The Thames has been described as one of the most highly invaded rivers in the world [57].

Range shifts due to climate change have been underway for at least several decades [58]. Species such as the spotted bass, native to North Africa, are now established in the estuary. Understanding how non-native species can make communities more resilient (in addition to the problems they may cause) is increasingly important. Deliberate introductions, frequently through oversight, but mainly on purpose, compose a significant part of ecosystems worldwide. There are many examples in the literature regarding deliberate introductions for conservation (assisted migration) or pest control purposes [59-62].

Food webs and other interactions are changing but need to be investigated as well. The populations of European-wide invasive species are typically seen to decline after varying periods of time (some in the short-term, others require a longer period of perhaps several years) to reduced levels following the initial population eruptions [63]. This may be due to integration with local food webs and acclimatisation to predators, disease and other factors constraining population size. However, short-term responses may be unhelpful in the long-term management of non-native species since it is a form of disturbance and can therefore provide additional opportunities for future colonisation, e.g., through the provision of additional habitat or ecological niche.

Pollution and reductions in oxygen saturation may have aided pollution-tolerant species from a competitive perspective, especially if they are air breathing or able to temporarily leave the water to avoid oxygen depleted areas of the river. These include 
the Chinese mitten crab, Eriocheir sinensis (H.Milne Edwards, 1853), eels Anguilla anguilla (Linnaeus, 1758), potential future colonisers including the walking catfish, Clarias batrachus (Linnaeus, 1758), already recorded in the Thames, and perhaps the Chinese river mussel, Sinanodonta woodiana (I.Lea, 1834), which is more pollution tolerant than the native unionid species. Some crabs including Eriocheir sinensis (H. Milne Edwards, 1853) are also known to have a high tolerance for ammonia possibly providing an advantage in water polluted by sewage [64].

Following disturbance due to climate or land use change, non-native species are sometimes better adapted, whereas native species may take long periods to recover if they do at all. The simplification of communities through declines in abundance and diversity means that non-native species sometimes increase biodiversity, and this has created conflicts between ecologists who wish to restore indigenous communities and those more interested in increasing biodiversity generally $[65,66]$. It is typical for an invasive species to acclimatise to local conditions through integration with food webs and adaptation to local climate, pathogens, predators and competition. This process may in turn include the alteration of the environment by the organism in terms of increased nutrient availability. The quagga mussel, Dreissena bugensis (Andrusov, 1897), for example, occurs in dense beds which increase phosphorous content of the water, which, when combined with changes to habitat caused by the establishment of large colonies, is believed to assist in the settlement of additional members of the Ponto-Caspian assemblage [67]. Shells of the American slipper Limpet, Crepidula fornicata (Linnaeus, 1758), form banks in the Thames Estuary. They produce copious amounts of pseudo-faeces which smother native oysters, transform the substrate, and enrich the nitrogen content of the water column [68]. Their reproductive cycle, as with the Chinese mitten crab, involves long residence times for larvae in the estuary, meaning that population dynamics are similarly regulated by phenology, nutrient levels, particulates (which increase larval survival), temperature and flows.

Reporting on invasive and non-native species populations is highly variable. For example, considerable attention has been paid to species that are invasive elsewhere such as the Chinese mitten crab and Dreissenid mussels [67], but relatively little consideration has been given to the vast slipper limpet population in the estuary. With hindsight, perhaps a disproportionate emphasis has been placed on charismatic species such as salmon and smelt and to the conservation of the slow-growing native unionid mussels, with monitoring of their limited return to the Thames following engineering work to improve the sewer system beginning in the 1950's [69]. These anomalies probably related to factors other than a comprehensive prioritisation strategy.

\section{Past Surveys, Current Management, Sampling and Assessments}

A programme of sampling species collected from cooling water intakes at London power stations (e.g., Lots Road, Brunswick Wharf, Blackwall Point) was initiated in the second half of the 20th century in cooperation with the Central Electricity Generating Board $[15,70]$. This followed major improvements to environmental conditions following the second period of restoration of the London sewer system in the 1960's. However, monitoring in the tidal Thames has been somewhat sporadic. Some work has been carried out by the Environment Agency, various ecological contractors, the Zoological Society London (ZSL) and others who have conducted monitoring of juvenile fish as well as certain historically important fish species including smelt, and used traps located in the river to assess eels. On occasion, seine netting is conducted in the river but there is no complete, long-term dataset and continuing work remains patchy. Since 1974, starting initially at West Thurrock Power Station, the water intake and, on occasion, outfall resting tank from cooling water systems at power stations in the Thames have been used for semi-quantitative assessment of aquatic species populations [5,71]. Water from a sub-tidal collection point in the river is passed through a screen filter before entering the station and items are collected in a pit. Since the rate of water intake is known, sampling for a specified period provides an indication of the abundance of animals in the immediate vicinity of the intake in terms 
of animals per litre. This system is convenient but has been problematic because operators were not trained to correctly identify to the species level. The location of the intakes is subject to bias attributable to attraction to warm water effluent from the power station (particularly when using condensers in the past), as well as migratory patterns which can cause animals to form spawning aggregations or accumulate as they converge from tributaries and progress downstream. In addition, larger animals are able to escape being sucked in at the intake and this was confirmed using trawls that illustrated that the number of larger fish were being underestimated [5].

The ZSL surveys benthic species from time to time at a location approximately $11 \mathrm{~km}$ upriver from Chiswick [51,52] and does have conservation programmes in place for certain species in the Thames including eels, smelt and seals. Notwithstanding this, the inherent value of the river within the overall context of London as well as the associated biota should merit a progressive and systematic monitoring programme conducted to the highest standards as one component of a comprehensive adaptation plan.

\section{Remediation, Restoration and Monitoring}

The Tideway project includes the expansion of the Beckton sewage treatment plant (downstream of the Thames Barrier), currently the largest sewage treatment plant in Europe. Increases in effluent may create problems in the estuary since not all harmful chemicals (including pharmaceuticals) or plastics are removed in the processing of sewage, and there may be challenges in the disposal of increased volumes of sludge (biosolids) produced by the treatment process. At the current time, biosolids from Beckton are recycled and used as fertilizer, although some waste is incinerated and disposed of as ash. Sludge contains nano and micro-plastics as well as pharmaceuticals [44,72,73], drug residues and other chemicals which can be blown or washed into the river as run-off from fields and landfills. The new Tideway Tunnel system will reduce sewage and effluent releases into the upper tidal Thames with most effluent entering the river closer to the estuary at Beckon. However, complete flushing will still be dependent on the tides, and some releases in the upper reaches will continue, especially during storms. These major changes to nutrient and run-off pollution, with a general shift from London down river towards the estuary will affect diverse elements of the ecosystem in both positive and negative ways providing an opportunity for a Before-After-Control-Impact (BACI) survey. Some species such as the non-native Asiatic clam will benefit from cleaner water but might also be affected by reduced nutrients and associated algal content. This will be the third major technological improvement to the Thames and the London sewer system after the 1850-1900 and the 1950-1980 sensitisation improvements [15]. However, it is now well understood that purely engineered solutions, while they may be robust, are not resilient but rather brittle and prone to failure. The Tideway project should improve dissolved oxygen levels within the upper tidal reaches. That will aide juvenile fish and fish species with higher oxygen requirements such as salmonids (salmon, smelt and shad), eels and to a lesser extent coarse species including pike, dace and zander (an introduced species), which are predominantly freshwater but do also occur in the upper reaches of the tidal part of the river. However, as with previous improvements, such changes could increase the receptiveness of the Thames ecosystem and open the door to further non-native species. The system can also respond in unexpected ways and it may be that established non-native or endemic species could become invasive and their numbers increase greatly. The pressures that will result, for example, dissolved oxygen increase and organic matter reductions, work selectively by boosting or inhibiting individual species through a complex interaction of effects. The Chinese mitten crab, for example, might be negatively affected by the reduction of nutrients and as a consequence, of the algae on which the crabs primarily feed.

There have been large population fluctuations within the tidal area and significant change is underway as estuarine species shift. However, a comprehensive Thames monitoring plan is missing. This would appear out of sync with regards to the Tideway project, for which a BACI survey would no doubt be very useful in assessing its effects on the ecology 
of the river. The absence of consistent monitoring practices is a surprising feature of the recent history of the Thames given the cost of improvement projects, long-term conservation work and the associated conservation areas. In fact, the general condition of the river and foreshore fall well below that of the surrounding areas, indicating that restoration, monitoring and stewardship within the overall context of the immediate neighbourhood have been disproportionately low. Sampling was initiated as a means of evaluating improvements resulting from modifications to the sewer system in the middle of the 20th century [5]. However, it was not part of a formal monitoring protocol and important information on the recovery of the river was lost, including data regarding the return of parasites [74].

\section{Conclusions}

Two major cycles of drastic deterioration of the Thames ecosystem and depletion of aquatic life, followed by technology-driven restorations over the last two centuries brought about strong ecosystem disturbances. Under the continuous pressure of anthropogenic impact, replacement of the Thames ecosystem rather than recovery becomes the most likely outcome. The Thames is home to an increasing number of non-native species, including pollution-tolerant species, whilst many native species undergo a continuing process of decline and extinction. Before engaging in the wholesale destruction of nonnative species (at significant cost) it is increasingly important to understand the possible future state of the ecosystem, especially given that once a species is lost it cannot be retrieved. Therefore, it is possible to damage future ecosystems through the arbitrary destruction of well adapted, non-native species as they respond to climate change and migrate to more suitable environmental conditions. Species persistence must also be viewed from within the context of ecosystem restoration. The ecology has changed and cannot be expected to revert to its previous condition as most of the changes are irreversible. For example, even brief periods of reduced oxygen levels in the ocean and coastal waters can have lasting effects on behaviour and reproduction through epigenetic effects on the current and future generations [75]. However, even in relatively undisturbed environments, restoration has not resulted in a return to prior pristine condition [76]. In recognition of these issues, some restoration practitioners in the field of woodlands have been working to develop a future-proof ecosystem using species that are not endemic, i.e., using transplants, while others have considered more heat-tolerant engineered organisms. Such self-assembly is already underway with many non-native species successfully integrating to existing ecosystems, particularly in the oceans $[77,78]$.

A more holistic view of restoration should be adopted with the emphasis on improving resilience and aiding adaptation of the complete socio-techno-ecological system, including anthropogenic impacts. The adaptive capacities of these ecosystems must be maintained by preserving a balance among heterogeneity, modularity and redundancy, tightening feedback loops to provide incentives for sound stewardship. Similar issues relate to flood and coastal defences, which must be developed as part of a complete sociotechnical solution [79]. It has therefore become increasingly important to collect data on species abundance within comprehensive monitoring programmes. The use of 'citizen science' and crowdsourcing has been largely insufficient and a larger, higher quality effort is required. It should be centred around organisations which embody high levels of expertise such as the National Biodiversity Network (NBN) and universities. In the case of the Thames, this means regular surveys and sampling with integration between other monitoring programmes around the country. Intelligent monitoring of species that may cause population eruptions, such as the Chinese mitten crab, especially following years of low flow, can provide an early warning of potential pest outbreaks in accordance with the governments' strategy around 'sleeper species' [80].

Supplementary Materials: The following are available online at https:/ /www.mdpi.com/article/10 .3390 / su13116045/s1, Figure S1: Relative positions of each of the maps shown in Figures 2, 3, 5 and 6 of the manuscript; Figure S2: Supplemental information on contaminants (Persistent Organic Pollu- 
tant (PCB)); Figure S3: Supplemental information on contaminants (single cores); Table S1: Supplemental information on contaminants (Mean pollutant concentrations).

Funding: This research received no external funding.

Conflicts of Interest: The funders had no role in the design of the study; in the collection, analyses or interpretation of data; in the writing of the manuscript; or in the decision to publish the results.

\section{References}

1. Lavery, S.; Donovan, B. Flood Risk Management in the Thames Estuary Looking Ahead 100 Years. Philos. Trans. R. Soc. A Math. Phys. Eng. Sci. 2005, 363, 1455-1474. [CrossRef] [PubMed]

2. Dawson, R.J.; Hall, J.W.; Bates, P.D.; Nicholls, R.J. Quantified Analysis of the Probability of Flooding in the Thames Estuary under Imaginable Worst-Case Sea Level Rise Scenarios. Int. J. Water Resour. Dev. 2005, 21, 577-591. [CrossRef]

3. Canal \& Rivers Trust: Fish Species. Available online: https://canalrivertrust.org.uk/enjoy-the-waterways/fishing/fish-species (accessed on 15 May 2021).

4. Deaker, D.J.; Agüera, A.; Lin, H.A.; Lawson, C.; Budden, C.; Dworjanyn, S.A.; Mos, B.; Byrne, M. The Hidden Army: Corallivorous Crown-of-Thorns Seastars Can Spend Years as Herbivorous Juveniles. Biol. Lett. 2020, 16, 20190849. [CrossRef] [PubMed]

5. Attrill, M.J. A Rehabilitated Estuarine Ecosystem: The Environment and Ecology of the Thames Estuary; Kluwer Academic Publishers: London, UK, 1998; pp. 116-121.

6. Zhang, H.; Han, J.; Chen, F.; Yuan, Q. Review on Plants Selection and Application Effects in Ecological Floating Beds Based on Water Purification. IOP Conf. Ser. Earth Environ. Sci. 2021, 647, 012186. [CrossRef]

7. Wei, Z.; Van Le, Q.; Peng, W.; Yang, Y.; Yang, H.; Gu, H.; Lam, S.S.; Sonne, C. A Review on Phytoremediation of Contaminants in Air, Water and Soil. J. Hazard. Mater. 2021, 403, 123658. [CrossRef]

8. Li, J.; Ianaiev, V.; Huff, A.; Zalusky, J.; Ozersky, T.; Katsev, S. Benthic Invaders Control the Phosphorus Cycle in the World's Largest Freshwater Ecosystem. Proc. Natl. Acad. Sci. USA 2021, 118, e2008223118. [CrossRef]

9. Vanderploeg, H.A.; Nalepa, T.F.; Jude, D.J.; Mills, E.L.; Holeck, K.T.; Liebig, J.R.; Grigorovich, I.A.; Ojaveer, H. Dispersal and Emerging Ecological Impacts of Ponto-Caspian Species in the Laurentian Great Lakes. Can. J. Fish. Aquat. Sci. 2002, 59, 1209-1228. [CrossRef]

10. Montgomery, D.R. Soil Erosion and Agricultural Sustainability. Proc. Natl. Acad. Sci. USA 2007, 104, 13268-13272. [CrossRef] [PubMed]

11. Matrosov, E.S.; Harou, J.J.; Loucks, D.P. A Computationally Efficient Open-Source Water Resource System Simulator-Application to London and the Thames Basin. Environ. Model. Softw. 2011, 26, 1599-1610. [CrossRef]

12. Department for Environment Food \& Rural Affairs (DEFRA). Water Abstraction Plan. Available online: https://www.gov.uk/ government/publications/water-abstraction-plan-2017/water-abstraction-plan (accessed on 15 May 2021).

13. Griffiths, R. An Essay to Prove That the Jurisdiction and Conservacy of the River of Thames. Printed for T. Longman in Paternoster-Row. 1758. Available online: https://thames.me.uk/PDF/1758RiverThamesGriffiths.pdf (accessed on 18 March 2020).

14. Bolton, D.K.; Croot, P.E.; Hicks, M.A. A History of the County of Middlesex: Volume 7, Acton, Chiswick, Ealing and Brentford, West Twyford, Willesden. Available online: https://www.british-history.ac.uk/vch/middx/vol7 (accessed on 15 May 2021).

15. Wood, L.B. The Restoration of the Tidal Thames.; Hilger: Bristol, UK, 1982; pp. 32-52.

16. Lombardo, A.; Franco, A.; Pivato, A.; Barausse, A. Food Web Modeling of a River Ecosystem for Risk Assessment of Down-theDrain Chemicals: A Case Study with AQUATOX. Sci. Total Environ. 2015, 508, 214-227. [CrossRef]

17. National Biodiversity Network (NBN) Atlas. Available online: https://nbnatlas.org/ (accessed on 10 April 2021).

18. Jackson, M.C.; Grey, J. Electronic Supplementary Material Accelerating Rates of Freshwater Invasions in the Catchment of the River Thames List of Freshwater Non-Indigenous Species Recorded as Established in the Thames Catchment. Available online: https:/ / www.academia.edu/2768923/Electronic_Supplementary_Material_for_Jackson_and_Grey_2013_Accelerating_ rates_of_freshwater_invasions_in_the_catchment_of_the_River_Thames (accessed on 5 April 2021).

19. ZSL (Zoological Society London) Guidance Document Conservation of Tidal Thames Fish through the Planning Process. 2016. Available online: http://www.lbhf.gov.uk/sites/default/files/section_attachments/guidance_document_conservation_of_tidal_ thames_fish_through_the_planning_process_october_2016.pdf (accessed on 15 May 2021).

20. The Zoological Society London. Available online: https://www.zsl.org/ (accessed on 15 May 2021).

21. Taylor, K.G.; Owens, P.N. Sediments in Urban River Basins: A Review of Sediment-Contaminant Dynamics in an Environmental System Conditioned by Human Activities. J. Soils Sediments 2009, 9, 281-303. [CrossRef]

22. Green, A.E.; Unsworth, R.K.F.; Chadwick, M.A.; Jones, P.J.S. Historical Analysis Exposes Catastrophic Seagrass Loss for the United Kingdom. Front. Plant Sci. 2021, 12, 629962. [CrossRef] [PubMed]

23. Tideway Tideway-Reconnecting London with the Tidal Thames. Thames Tideway, 2019. Available online: https://www.tideway. london/ (accessed on 18 March 2020)

24. Department for Environment Food \& Rural Affairs (DEFRA). Creating a River Thames Fit for Our Future: A Strategic and Economic Case for the Thames Tunnel. Available online: https://assets.publishing.service.gov.uk/government/uploads/system/ uploads/attachment_data/file/471847/thames-tideway-tunnel-strategic-economic-case.pdf (accessed on 15 May 2021).

25. Talling, P. London's Lost Rivers; Random House Books: London, UK, 2011; pp. 10-50. 
26. Haas, A.F.; Fairoz, M.F.M.; Kelly, L.W.; Nelson, C.E.; Dinsdale, E.A.; Edwards, R.A.; Giles, S.; Hatay, M.; Hisakawa, N.; Knowles, B.; et al. Global Microbialization of Coral Reefs. Nature Microbiol. 2016, 1, 16042. [CrossRef] [PubMed]

27. Garcia-Armisen, T.; Vercammen, K.; Passerat, J.; Triest, D.; Servais, P.; Cornelis, P. Antimicrobial Resistance of Heterotrophic Bacteria in Sewage-Contaminated Rivers. Water Res. 2011, 45, 788-796. [CrossRef]

28. Rosi, E.J.; Bechtold, H.A.; Snow, D.; Rojas, M.; Reisinger, A.J.; Kelly, J.J. Urban Stream Microbial Communities Show Resistance to Pharmaceutical Exposure. Ecosphere 2018, 9, e02041. [CrossRef]

29. Plaas, H.E.; Paerl, H.W. Toxic Cyanobacteria: A Growing Threat to Water and Air Quality. Environ. Sci. Technol. 2021, 55, 44-64. [CrossRef]

30. Aguilera, A.; Klemenčič, M.; Sueldo, D.J.; Rzymski, P.; Giannuzzi, L.; Martin, M.V. Cell Death in Cyanobacteria: Current Understanding and Recommendations for a Consensus on Its Nomenclature. Front. Microbiol. 2021, 12, 631654. [CrossRef] [PubMed]

31. Pan, M.; Lyu, T.; Zhan, L.; Matamoros, V.; Angelidaki, I.; Cooper, M.; Pan, G. Mitigating Antibiotic Pollution Using Cyanobacteria: Removal Efficiency, Pathways and Metabolism. Water Res. 2021, 190, 116735. [CrossRef]

32. Thames Tideway Tunnel Application for Development Consent: Resilience to Change; Thames Tideway: London, UK, 2013 ; p. 6.

33. Wurtsbaugh, W.A.; Paerl, H.W.; Dodds, W.K. Nutrients, Eutrophication and Harmful Algal Blooms along the Freshwater to Marine Continuum. Wiley Interdiscip. Rev. Water 2019, 6, e1373.

34. Diaz, R.J.; Rosenberg, R. Spreading Dead Zones and Consequences for Marine Ecosystems. Science 2008, 321, 926-929. [CrossRef]

35. Brand, J.H.; Spencer, K.L.; O'shea, F.T.; Lindsay, J.E. Potential Pollution Risks of Historic Landfills on Low-Lying Coasts and Estuaries. Wiley Interdiscip. Rev. Water 2018, 5, e1264. [CrossRef]

36. O'Shea, F.T.; Cundy, A.B.; Spencer, K.L. The Contaminant Legacy from Historic Coastal Landfills and Their Potential as Sources of Diffuse Pollution. Mar. Pollut. Bull. 2018, 128, 446-455. [CrossRef] [PubMed]

37. Thomas, K.V.; Hurst, M.R.; Matthiessen, P.; McHugh, M.; Smith, A.; Waldock, M.J. An Assessment of in Vitro Androgenic Activity and the Identification of Environmental Androgens in United Kingdom Estuaries. Environ. Toxicol. Chem. 2002, 21, 1456-1461. [CrossRef] [PubMed]

38. Letsinger, S.; Kay, P.; Rodríguez-Mozaz, S.; Villagrassa, M.; Barceló, D.; Rotchell, J.M. Spatial and Temporal Occurrence of Pharmaceuticals in UK Estuaries. Sci. Total Environ. 2019, 678, 74-84. [CrossRef]

39. Nielsen, S.V.; Frausing, M.; Henriksen, P.G.; Beedholm, K.; Baatrup, E. The Psychoactive Drug Escitalopram Affects Foraging Behavior in Zebrafish (Danio Rerio). Environ. Toxicol. Chem. 2019, 38, 1902-1910. [CrossRef] [PubMed]

40. Polverino, G.; Martin, J.M.; Bertram, M.G.; Soman, V.R.; Tan, H.; Brand, J.A.; Mason, R.T.; Wong, B.B.M. Psychoactive Pollution Suppresses Individual Differences in Fish Behaviour. Proc. R. Soc. B Biol. Sci. 2021, 288, 20202294. [CrossRef]

41. Yin, L.; Wang, B.; Yuan, H.; Deng, S.; Huang, J.; Wang, Y.; Yu, G. Pay Special Attention to the Transformation Products of PPCPs in Environment. Emerg. Contam. 2017, 3, 69-75. [CrossRef]

42. Fatta-Kassinos, D.; Vasquez, M.I.I.; Kümmerer, K. Transformation Products of Pharmaceuticals in Surface Waters and Wastewater Formed during Photolysis and Advanced Oxidation Processes-Degradation, Elucidation of Byproducts and Assessment of Their Biological Potency. Chemosphere 2011, 85, 693-709. [CrossRef]

43. Vane, C.H.; Turner, G.H.; Chenery, S.R.; Richardson, M.; Cave, M.C.; Terrington, R.; Gowing, C.J.B.B.; Moss-Hayes, V. Trends in Heavy Metals, Polychlorinated Biphenyls and Toxicity from Sediment Cores of the Inner River Thames Estuary, London, UK Environ. Sci. Process. Impacts 2020, 22, 364-380. [CrossRef]

44. Lu, Q.; Jürgens, M.D.; Johnson, A.C.; Graf, C.; Sweetman, A.; Crosse, J.; Whitehead, P. Persistent Organic Pollutants in Sediment and Fish in the River Thames Catchment (UK). Sci. Total Environ. 2017, 576, 78-84. [CrossRef]

45. Michels, J.; Stippkugel, A.; Lenz, M.; Wirtz, K.; Engel, A. Rapid Aggregation of Biofilm-Covered Microplastics with Marine Biogenic Particles. Proc. R. Soc. B Biol. Sci. 2018, 285, 20181203. [CrossRef]

46. Kole, P.J.; Löhr, A.J.; Van Belleghem, F.G.A.J.; Ragas, A.M.J. Wear and Tear of Tyres: A Stealthy Source of Microplastics in the Environment. Int. J. Environ. Res. Public Health 2017, 14, 1265. [CrossRef] [PubMed]

47. Brahney, J.; Mahowald, N.; Prank, M.; Cornwell, G.; Klimont, Z.; Matsui, H.; Prather, K.A. Constraining the Atmospheric Limb of the Plastic Cycle. Proc. Natl. Acad. Sci. USA 2021, 118, e2020719118. [CrossRef] [PubMed]

48. Wallingford, H.R. Thames 2D Base Model 2012. Available online: https://www.pla.co.uk/assets/NA012_0609_MAL_Thames_ 2D_base_model.pdf (accessed on 15 May 2021).

49. Nogales, B.; Lanfranconi, M.P.; Piña-Villalonga, J.M.; Bosch, R. Anthropogenic Perturbations in Marine Microbial Communities. FEMS Microbiol. Rev. 2010, 35, 275-298. [CrossRef]

50. Andrews, M.J.; Rickard, D.G. Rehabilitation of the Inner Thames Estuary. Mar. Pollut. Bull. 1980, 11, 327-332. [CrossRef]

51. Andrews, M.J. Thames estuary: Pollution and recovery. In Effects of Pollutants at the Ecosystem Level; Sheehan, P.J., Miller, D.R., Butler, G.C., Bourdeau, P.H., Eds.; John Wiley \& Sons: New York, NY, USA, 1984; pp. 195-227.

52. Worden, L.; Botsford, L.W.; Hastings, A.; Holland, M.D. Frequency Responses of Age-Structured Populations: Pacific Salmon as an Example. Theor. Popul. Biol. 2010, 78, 239-249. [CrossRef]

53. Measham, N. Riverfly Census 2015. Salmon Trout Conserv. UK. 2015. Available online: https://salmon-trout.org/wp-content/ uploads /2017/08/2015-Report_Riverfly-Census.pdf (accessed on 15 May 2021). 
54. Ainscough, J.; Barker, J.; Pecorelli, J. Freshwater Bivalve Survey in the Upper Tidal Thames. UK Eur. Conserv. Program. 2015. Available online: https://www.zsl.org/sites/default/files/media/2015-03/ReportonZSLsFreshwaterBivalveSurveyintheUpperTidalThames2 015.pdf (accessed on 15 May 2021).

55. Pecorelli, J. Freshwater Mussel Survey in the Upper Tidal Thames. 2018. Available online: https:/ /www.zsl.org/sites/default/ files/media/2018-06/INNSSurveyReport_ZSL2017_Final_07.02.18_0.pdf (accessed on 15 May 2021).

56. Cohen, A.N.; Carlton, J.T. Accelerating Invasion Rate in a Highly Invaded Estuary. Science 1998, 279, 555-558. [CrossRef] [PubMed]

57. Jackson, M.C.; Grey, J. Accelerating Rates of Freshwater Invasions in the Catchment of the River Thames. Biol. Invasions 2013, 15, 945-951. [CrossRef]

58. Pecl, G.T.; Araújo, M.B.; Bell, J.D.; Blanchard, J.; Bonebrake, T.C.; Chen, I.-C.; Clark, T.D.; Colwell, R.K.; Danielsen, F.; Evengård, B.; et al. Biodiversity Redistribution under Climate Change: Impacts on Ecosystems and Human Well-Being. Science 2017, 355, eaai9214. [CrossRef] [PubMed]

59. Etterson, J.R.; Cornett, M.W.; White, M.A.; Kavajecz, L.C. Assisted Migration across Fixed Seed Zones Detects Adaptation Lags in Two Major North American Tree Species. Ecol. Appl. 2020, 30, e02092. [CrossRef]

60. Sáenz-Romero, C.; Mendoza-Maya, E.; Gómez-Pineda, E.; Blanco-García, A.; Endara-Agramont, A.R.; Lindig-Cisneros, R.; López-Upton, J.; Trejo-Ramírez, O.; Wehenkel, C.; Cibrián-Tovar, D.; et al. Recent Evidence of Mexican Temperate Forest Decline and the Need for Ex Situ Conservation, Assisted Mi-gration, and Translocation of Species Ensembles as Adaptive Management to Face Projected Climatic Change Impacts in a Megadiverse Country. Can. J. For. Res. 2020, 50, 843-854. [CrossRef]

61. Sáenz-Romero, C.; O'neill, G.; Aitken, S.N.; Lindig-Cisneros, R. Assisted Migration Field Tests in Canada and Mexico: Lessons, Limitations, and Challenges. Forests 2021, 12, 9. [CrossRef]

62. Bladon, A.; Donald, P.; Collar, N.; Deng, J.; Dadacha, G.; Wondafrash, M.; Green, R. Climatic change and extinction risk of two globally threatened Ethiopian endemic bird species. PLOS ONE 2021, 16, e0249633. [CrossRef]

63. Simberloff, D.; Gibbons, L. Now You See Them, Now You Don't!-Population Crashes of Established Introduced Species. Biol. Invasions 2004, 6, 161-172. [CrossRef]

64. Weihrauch, D.; Morris, S.; Towle, D.W. Ammonia Excretion in Aquatic and Terrestrial Crabs. J. Exp. Biol. 2004, 207, 4491-4504. [CrossRef] [PubMed]

65. Briggs, J.C. Rise of Invasive Species Denialism? A Response to Russell and Blackburn. Trends Ecol. Evol. 2017, 32, 231-232. [CrossRef]

66. Crowley, S.L.; Hinchliffe, S.; Redpath, S.M.; McDonald, R.A. Disagreement About Invasive Species Does Not Equate to Denialism: A Response to Russell and Blackburn. Trends Ecol. Evol. 2017, 32, 228-229. [CrossRef] [PubMed]

67. Gallardo, B.; Aldridge, D.C. Is Great Britain Heading for a Ponto-Caspian Invasional Meltdown? J. Appl. Ecol. 2015, 52, 41-49. [CrossRef]

68. Fitzgerald, A. Slipper Limpet Utilisation and Management 2007. Available online: http://www.shellfish.org.uk/files/Literature/ Projects-Reports /0701-Slipper_Limpet_Report_Final_Small.pdf (accessed on 15 May 2021).

69. Griffiths, A.M.; Ellis, J.S.; Clifton-Dey, D.; Machado-Schiaffino, G.; Bright, D.; Garcia-Vazquez, E.; Stevens, J.R. Restoration versus Recolonisation: The Origin of Atlantic Salmon (Salmo Salar L.) Currently in the River Thames. Biol. Conserv. 2011, 144, $2733-2738$. [CrossRef]

70. Wheeler, A. The Tidal Thames: The History of a River and Its Fishes; Routledge \& Kegan Paul: London, UK, 1980; pp. 89-108.

71. Clark, P.F.; Rainbow, P.S.; Robbins, R.S.; Smith, B.; Yeomanst, W.E.; Thomast, M.; Dobson, G. The Alien Chinese Mitten Crab, Eriocheir Sinensis (Crustacea: Decapoda: Brachyura), in the Thames Catchment. J. Mar. Biol. Ass. UK 1998, 78, $1215-1221$. [CrossRef]

72. Smith, S.R. Organic Contaminants in Sewage Sludge (Biosolids) and Their Significance for Agricultural Recycling. Philos. Trans. R. Soc. A Math. Phys. Eng. Sci. 2009, 367, 4005-4041. [CrossRef]

73. Richardson, S.D.; Ternes, T.A. Water Analysis: Emerging Contaminants and Current Issues. Anal. Chem. 2018, 90, 398-428. [CrossRef]

74. Munro, M.; Whitfield, P.; Lee, S. Host-parasite interactions: Case studies of parasitic infections in migratory fish. In A Rehabilitated Estuarine Ecosystem: The Environment and Ecology of the Thames Estuary; Attrill, M.J., Ed.; Springer US: Boston, MA, USA, 1998; pp. 141-167.

75. Breitburg, D.; Levin, L.A.; Oschlies, A.; Grégoire, M.; Chavez, F.P.; Conley, D.J.; Garçon, V.; Gilbert, D.; Gutiérrez, D.; Isensee, K.; et al. Declining Oxygen in the Global Ocean and Coastal Waters. Science 2018, 359, eaam7240. [CrossRef] [PubMed]

76. Levin, S.A.; Lubchenco, J. Resilience, Robustness, and Marine Ecosystem-Based Management. Bioscience 2008, 58, 27-32. [CrossRef]

77. Paniw, M.; James, T.D.; Archer, C.R.; Römer, G.; Levin, S.; Compagnoni, A.; Che, J.; Bennett, C.J.M.; Mooney, A.; Childs, D.Z.; et al. The Myriad of Complex Demographic Responses of Terrestrial Mammals to Climate Change and Gaps of Knowledge: A Global Analysis. J. Anim. Ecol. 2021, Online ahead of print. [CrossRef]

78. Chaudhary, C.; Richardson, A.J.; Schoeman, D.S.; Costello, M.J. Global Warming Is Causing a More Pronounced Dip in Marine Species Richness around the Equator. Proc. Natl. Acad. Sci. USA 2021, 118, e2015094118. [CrossRef] [PubMed] 
79. Mastrángelo, M.E.; Pérez-harguindeguy, N.; Enrico, L.; Bennett, E.; Lavorel, S.; Cumming, G.S.; Abeygunawardane, D.; Amarilla, L.D.; Burkhard, B.; Egoh, B.N.; et al. Key Knowledge Gaps to Achieve Global Sustainability Goals. Nat. Sustain. 2019, 2, $1115-1121$. [CrossRef]

80. Department for Environment Food \& Rural Affairs (DEFRA). The National Adaptation Programme and the Third Strategy for Climate Adaptation Reporting. 2018. Available online: https://assets.publishing.service.gov.uk/government/uploads/system/ uploads/attachment_data/file/727252/national-adaptation-programme-2018.pdf (accessed on 15 May 2021). 